\title{
The Effect of Students' Learning Styles to Their Academic Success
}

\author{
Murat Gokalp \\ Faculty of Education, 19 May University, Samsun, Turkey \\ Email: gokalpm@omu.edu.tr
}

Received August $6^{\text {th }}, 2013$; revised September $6^{\text {th }}, 2013$; accepted September $13^{\text {th }}, 2013$

\begin{abstract}
Copyright (C) 2013 Murat Gokalp. This is an open access article distributed under the Creative Commons Attribution License, which permits unrestricted use, distribution, and reproduction in any medium, provided the original work is properly cited.
\end{abstract}

\begin{abstract}
This study was aimed to evaluate the learning styles of education faculty students and to determine the effect of their success and relationship between their learning styles and academic success. The population of this study is comprised of the students of Education Faculty in 19 May University and the sample includes 140: 68 art, 72 pre-school teacher department students. Depending on the results obtained from pre-test, it was aimed to improve students' knowledge and skills in studying. There was a significant difference between the scores of pre- and post-tests. The significant relationship between the scores of post-test and the student success revealed that they learned how to study effectively. The validity and reliability of the test were determined by considering the Cronbach alpha coefficients for each and all of the items. The study has found statistically significant differences between the results of the first and final applications of the subtests on learning styles and academic success; those subtests covered the items as learning, planned study, effective reading, listening, writing, note taking, using the library, getting prepared for and taking exams, class participation and motivation.
\end{abstract}

Keywords: Study Skills; Learning; Education; Success; Learning Styles

\section{Introduction}

It is commonly believed that learning styles are not really concerned with "what" learners learn, but rather "how" they prefer to learn and it is also an important factor for students' academic achievement and attitudes. Students have different strengths and preferences in the ways how they take in and process information which is to say, they have different learning styles. Some prefer to work with concrete information (experimental data, facts) while others are more comfortable with abstractions (symbolic information, theories Mathematical models). It is common to describe and classify unique styles in many domains. For example, there are various architectural styles that may be classified by elements of form, material, time period, and indigenous geographic region. Similarly, there are many distinct literary styles, classified by form, genre, and technique. However, style is not a term that is particularly well-associated with the processes that comprise the complex mechanism of individual learning.

However, recent research suggests that the style by which one learns and applies knowledge is an important characteristic to consider in the aggregate educational processes (Graf, Lin, \& Kinshuk, 2008; Kolb \& Kolb, 2009; Syler et al., 2006; Thorton, Haskell \& Libby, 2006; Zualkernan, Allert, \& Qadah, 2006). Acknowledgement of unique learning styles is an attempt to characterize the complex processes by which one acquires knowledge (Kolb, Rubin, \& McIntyre, 1974). Learning style may be thought of as a formulation of preconceptions by an individual engaged in the activity of learning (Biggs \& Moore, 1993). The Dual Coding Theory for example states that information is processed through one of two usually independent channels (Beacham et al., 2002).

A learning style is defined as the characteristics, strengths and preferences in the way how people receive and process information (Felder \& Silverman, 1988; Allinson \& Hayes, 1996; Felder \& Brent, 2005; Hsieh et al., 2011). It refers to the fact that every person has his or her own method or set of strategies when learning (Schemeck 1988; ChanLin, 2009; Ford $\&$ Chen, 2000; Weinstein, 1996). Learning styles are not dichotomous (black or white, present or absent). Learning styles generally operate on a continuum or on multiple, intersecting continua (Ehrman, 1996; Dunn, 1983; Reid, 1995; McDermott \& Beitman, 1984).

There are many debates within the higher education community on how teaching or teaching effectiveness may be defined, for instance, defining effective teaching as "that which produces beneficial and purposeful student learning through the use of appropriate procedures including both teaching and learning in their definition", and defining effective teaching as the "creation of situations in which appropriate learning occurs; shaping those situations is what successful teachers have learned to do effectively". Learning styles are generally considered as characteristic, cognitive, affective, and psychological behaviors that serve as relatively stable indicators of how learners perceive, interact with, and respond to a learning environment.

Even though there are various definitions of learning styles which are unique and steady, methods of effective learning and information processing are widely accepted (Butler, 1987; Canfield \& Canfield, 1988; Keefe, 1991; Weinstein, 1996). A good 
strategic learner must understand how to identify their learning goal, integrate the learning style, apply proper skills, and be self-regulated to achieve the best results from learning (Paris \& Wingrad, 1990; Zimmerman \& Schunk, 2001; Wadsworth, Husman, \& Duggan, 2007). Teaching methods also vary. Teaching and learning are the two sides of a coin. The most accepted criterion for measuring good teaching is the amount of student learning that course. There are consistently high correlations between students' ratings of the "amount learned" in the course and their overall ratings of the teacher and the course. Those who learned more gave their teachers higher ratings. Some instruct lecture, others demon strate or discuss; some focus on principles and others on applications; some emphasize memory and others on understanding. In literature there exist numerous learning styles and learning style models. The differences among definitions and models result from the fact that learning is achieved at different dimensions and that theorists define learning styles by focusing on different aspects (Shuell 1986; Dede, Brown-L'Bahy, Ketelhut, \& Whitehouse, 2004; Jensen, 1998). Explaining that "different ways used by individuals to process and organize information or to respond to environmental stimuli refer to their learning styles", defines learning style as a sort of way of thinking, comprehending and processing information. To Kolb (1984), learning style is a method of personal choice to perceive and process information. In this sense, learning style is, on one hand, sensory and, on the other hand, mental. In the 1940s Isabel Briggs Myers developed the Myers-Briggs Type Indicator (MBTI), an instrument that measures, among other things, the degree to which an individual prefers sensing or intuition. In the succeeding decades the MBTI has been given to hundreds of thousands of people and the resulting profiles have been correlated with career preferences and aptitudes, management styles, learning styles, and various behavioral tendencies (Myers, 1980; Kolb, 1984). The complex mental processes by which perceived information is converted into knowledge can be conveniently grouped into two categories: active experimentation and reflective observation. Active experimentation Kolb showed that learning styles could be seen on a continuum running from: 1) concrete experience: being involved in a new experience, 2) reflective observation: watching others or developing observations about own Experience, 3) abstract concept ualization: creating theories to explain observations, 4) active experimentation: using theories to solve problems, and make decisions. Kolb's learning styles gave examples of how one might teach to them: 1) for the concrete experiencer: offer labs, field work, observations or videos, 2) for the reflective observer: use logs, journals or brainstorming, 3) for the abstract conceptualizer: lectures, papers and analogies work well, 4) for the active experimenter: offer simulations, case studies and homework. It involves doing something in the external world with the information to discuss it or explainit or test it in some way and reflective observation involves examining and manipulating the information introspectively. Induction is a reasoning progression that proceeds from particulars (observations, measurements, and data) to generalities (governing rules, laws, and theories). Deduction proceeds in the opposite direction. In induction one infers principles; in deduction one deduces consequences (Friedman \& Alley, 1984; Rose, 1998; Dervan \& Lawrence, 1982).

Active experimentation involves doing something in the external world with the information to discuss it or explainit or test it in some way and reflective observation involves examin- ing and manipulating the information introspectively. The simplest and most common form of which involves presenting the information both textually and visually. "Whole brain" learning is known to be a far more effective way to learn. The better connected the two halves of the brain are, the greater the potential of the brain for learning and creativity is. Sequential learners follow linear reasoning processes when solving problems; global learners make intuitive leaps and may be unable to explain how they came up with solutions. Sequential learners can work with material when they understand it partially or superficially, while global learners may have great difficulty to do so. Visual learners remember best what they see: pictures, diagrams, flow charts, time lines, films, and demonstrations. Verbal learners get more out of words: written and spoken explanations. Everyone learns more when information is presented both visually and verbally. Visual learners most effectively process visual information; auditory learners (Whitman \& Schwenk, 1984; Miller, 2001) understand best through hearing; and kinesthetic/tactile learners learn through touch and movement. A study conducted by Specific Diagnostic Studies found that 29 percent of all students in elementary and secondary schools are visual learners, 34 percent learn through auditory means, and 37 percent learn best through kinesthetic/tactile modes. Knowledge, attitudes and skills are the content areas needed to produce a well-trained professional. In short, learning style preferences of students cannot be the sole basis for designing instruction, and prescription based on diagnosis must be tentative, varied, monitored, and verified. Project tasks that allow students to use their individual learning styles are not a direct path to higher-order thinking. However, it is possible to create products that reflect shallow and superficial thought. In the mid- to late 1970 s, paradigms began to be developed to identify the more external, applied modes of learning styles.

Style refers to a pervasive quality in the learning strategies or the learning behavior of an individual, "a quality that persists though the content may change" (Fischer \& Fischer, 1979; Ennis, 2000; Gregorc, 1979; Dale 1969; Diaz \& Cartnal, 1999; Smith \& Renzulli 1984).

One of the components in the Dunn and Dunn model of learning styles which probably has some biological basis is time-of-day preference.

Indeed, recent research points to a genetic influence, or "clock gene", which is linked to peak alert time. Understanding students' learning styles has been identified as an important element for e-learning development, delivery and instruction, which can lead to improved student performance (Shih \& Gamon, 2002; Davidman, 1981; Archer et al., 2003).

A simple awareness of differences in student learning styles is vital for educators in order to aid the learning process. Effective instruction reaches out to all students, not just those with one particular learning style. Students taught entirely with methods antithetical to their learning style may be made too uncomfortable to learn effectively, but they should have at least some exposure to those methods to develop a full range of learning skills and strategies. Most people extract and retain more information from visual presentations than from written or spoken prose.

Generally, a rich data have been obtained through studies on learning styles; however, the data have rarely been exploited by designers of instructional programs thereby a greater understanding of learners' approaches to learning can be obtained. 
All information which becomes the subjective life of an individual after giving meaning process may have individual-specific differences in ensuring permanence of learning and remembering. To describe learning styles and to analyze which factors affect learning styles, many studies have been conducted for years. Learners have unique ways of learning, which may greatly affect the learning process and consequently their academic achievement and its outcomes. Learners learn in many ways by seeing and hearing; reflecting and acting; reasoning logically and intuitively; memorizing and visualizing. Researchers drew a distinction between learning styles and strategies focusing on the ways they differ from each other. To teach and learn more effectively, instructors and learners need to better understand and appreciate these individual differences and how they affect the learning process. Learning styles have been extensively discussed in the educational psychology literature Students will learn content better through their preferred learning style. We know that teachers tend to teach in their own preferred learning style. Learning style includes how they approach learning, experience learning and utilize information. Filling in questionnaires and quizzes to determine preferred learning styles can be fun but will not be effective unless they become part of an ongoing program of learning how to learn for students. Learning styles refer to the variations in your ability to accumulate as well as assimilate information. It is quite easy to determine and you may have already had an idea that you might have a particular learning style. In other cases, it may not be quite easy to identify.

\section{Method}

Data were collected by applying an evaluation test for studying and learning activities Developed by the researcher, and also by examining student grades. The test includes 106 questions about 10 sub topics covering Learning, Planned study, Effective Reading, Listening, Class Participation, Writing, Using Library, Getting prepared for and Taking Exams, Motivation, Note Taking, The "t-test" was used in order to determine whether there was a difference between test scores in preliminary and final applications of the items involved. A correlation analysis was used to determine the relationship between pre and post test scores in each item and also between these scores and student success.

Participant and Settings: The population of this study is comprised of the students of Ondokuz Mayis University Education Faculty and the sample includes 140: 68 art, 72 pre-school teacher department students. The study protocol was approved by the school administration and the permission was obtained. The students were informed about the purpose and content of the study; they were told that their participation was voluntary and their verbal consent was obtained. This study was aimed to evaluate the learning styles of education faculty students and to determine the effect of their success and relationship between their learning styles and academic success. The validity and reliability of the test was determined by considering the Cronbach Alpha coefficients for each and all of the items. SPSS 15 for windows was used for this purpose. This coefficient was determined for each of the items and these coefficients are illustrated in Table 1. Study is limited 140, 68 art, 72 pre-school teacher department students at Ondokuz Mayis University Education Faculty.
Table 1.

Cronbach values for each of the items.

\begin{tabular}{cc}
\hline Items & $\mathbf{( N = 1 0 6 )}$ \\
\hline Learning & 0.86 \\
Planned study & 0.84 \\
Active reading & 0.85 \\
Listening & 0.79 \\
Class participation & 0.84 \\
Writing & 0.89 \\
Using the Library & 0.78 \\
Getting Prepared for and Taking the Exam & 0.86 \\
Motivation & 0.71 \\
Note taking & 0.85 \\
\hline
\end{tabular}

\section{Research Results}

The test was given to the students at the beginning and the end of the academic year. Findings related to all items are demonstrated in Table 2.

140 students who participated in the study had higher mean scores in post-tests and the difference between pre and post test mean scores was statistically significant $(p>0.05)$. A positive relationship was observed between the scores of pre and post tests on sub topics. The relationship between the pre and posttest and grades of the students was examined by correlation analysis. The findings are given in Table 3.

According to these results, a positive correlation was found between the scores of post-test on the items of learning, planned study, effective reading and grades while there was weak negative correlation between the scores of pre-tests on the items of learning, planned study, effective reading and grades at the significant level of 0.05 . While the correlation between pre-tests scores in the items of listening and note taking and grades wasn't significant, the correlation between the scores of post-test and grades was strongly positive. While there was a weak negative correlation between the scores of pre-tests on the items of class participation, writing, using library, getting prepared for and taking an exam and grades $(\mathrm{r}=-0.007, \mathrm{r}=$ $-0.022, r=-0.018, r=-0.040$ respectively), the relationship between the scores of posttest and grades was reduced to a very weak negative correlation $(\mathrm{r}=-0.300, \mathrm{r}=-0.008, \mathrm{r}=0.034, \mathrm{r}=$ -0.086 respectively).

\section{Conclusion and Discussion}

The study has found statistically significant differences between the results of the first and final applications of the subtests on learning styles and academic success; those subtests covered the items of learning, planned study, effective reading, listening, writing, note taking, using the library, getting prepared for and taking exams, class participation and motivation.

The students who did not have study plans or could not follow their plans at the beginning of the term were observed to have a well-planned study program at the end of the term.

In addition to the problem of the complexity of identifying learning styles, Corbett and Smith (1984) discuss the problem of the reliability of such learning style instruments as the Edmonds Learning Style Identification Exercise. Their study 
Table 2.

The difference between the pre and post-test.

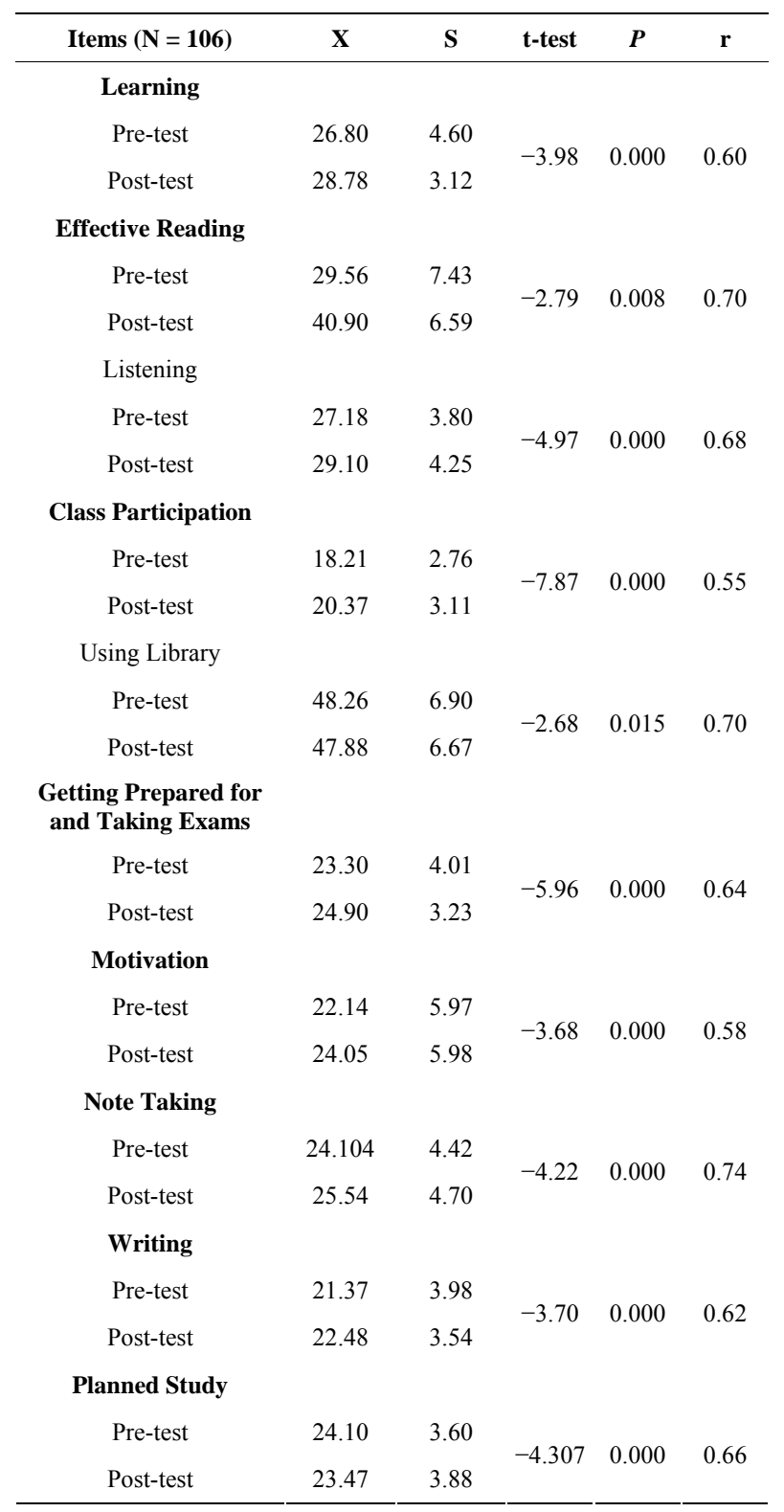

showed that individual variation tended to be consistent and therefore suggestive of external reliability but that group variation lacked consistency and therefore tended to be less reliable tolist three shortcomings of existing self-assessment instruments: 1) The instruments are exclusive (i.e., they focus on certain variables); 2) the students may not self-report accurately; and 3 ) the students have adapted for so long that they may report on adapted preferences. Finally, McLaughlin (1981), Daniel, Price and Merrifield (2002) studied the effect of learning styles and learning environments on the distance education of students in the department of physiotherapy. Werner (2003) studies the effect of self-awareness about learning styles on the selection of learning strategies and the development of comprehension process. Kolb Learning Styles Inventory was used to identify the learning styles of forty-one adult learners who were observed for six months. The subjects tackled strategies
Table 3.

Correlation between items and grades.

\begin{tabular}{cc}
\hline Items (N $=$ 106) & Grader \\
\hline Learning & \\
Pre-test & -0.080 \\
Post-test & 0.004 \\
Effective Reading & \\
Pre-test & -0.036 \\
Post-test & 0.009 \\
Listening & \\
Pre-test & -0.030 \\
Post-test & 0.076 \\
Class Participation & \\
Pre-test & 0.007 \\
Post-test & 0.300 \\
Using Library & \\
Pre-test & \\
Post-test & 0.018 \\
Getting Prepared for and Taking Exams & 0.034 \\
Pre-test & \\
Post-test & 0,040 \\
Motivation & 0,086 \\
Pre-test & \\
Post-test & -0.112 \\
Note Taking & -0.107 \\
Pre-test & \\
Post-test & -0.048 \\
Writing & -0.020 \\
Pre-test & \\
Post-test & -0.022 \\
Planned Study & Pre-test \\
Post-test & -0.008 \\
& \\
\hline & 0.017 \\
\hline & 0.045 \\
\hline
\end{tabular}

and techniques on the basis of time, keeping the memory, reading, note-taking and decision-making.

The data concerning the learning preferences of subjects were collected through the compositions they wrote. The findings of the study show that the learning types (strategies) preferred according to the learning styles of the subjects were not the appropriate strategies. According to the findings of studies conducted by using the Kolb Learning Style Inventory, learning styles vary depending on individuals' majors (social sciences, natural sciences etc.) and occupations (Kolb, Boyatzis, \& Mainemelis, 2001). Kolb, Wolfe, Fry, Bushe and Gish (1981) suggest that there are disciplinary differences in learning styles.

\section{Recommendations}

Programs should be designed to improve students' learning styles and learning strategies for all levels to make the teaching and learning process more effective.

It is also recommended that course design should be flexible enough to reach a variety of learning styles. One such example is described by Bates and Leary (2001) which provides a four tier delivery approach whereby the student progresses sequentially through each level based upon their learning needs.

The students should be properly guided and given incentives to select individual learning styles that are appropriate and applicable in their environment for them to achieve their personal academic objective. The students should adopt a suitable learning style that would be beneficial to them. 
If distribution of learning styles is similar between students enrolled in both vocational and undergraduate academic programs and if dominant learning style doesn't appear to have a significant effect on academic performance, how can determination of learning style be helpful to the student or instructor?

\section{REFERENCES}

Allinson, C., \& Hayes, J. (1996). The cognitive style index: A measure of intuition analysis for organizational research. Journal of Management Studies, 33, 119-135. http://dx.doi.org/10.1111/j.1467-6486.1996.tb00801.x

Archer, S. N., Robilliard, D. L., Skene, D. J., Smits, M., Williams, A., Arendt, J., \& Von Schantz, M. (2003). A length polymorphism in the Circadian clock gene Per3 is linked to delayed sleep phase syndrome and extreme diurnal preference. Sleep, 26, 413-415.

Beacham, N., Elliott, A., Alty, L., \& Al-Sharrah, A. (2002). Media combinations and learning styles: A dualcoding approach. Word Conference on Educational Ultimedia, Hypermedia \& Telecomunicaciones. Denver, CO.

Bates, B., \& Leary, J. (2001). Supporting a range of learning styles using a taxonomy-based design framework approach. Proceedings of the Annual Conference of Australian Society for Computers in Learning and Tertiary Education.

http://www.ascilite.org.au/conferences/melbourne01/pdf/papers/bates b.pdf

Biggs, J., \& Moore, P. (1993). The process of learning (3rd ed.). New York: Prentice Hall.

Butler, K. A. (1987). Learning \& teaching style: In theory \& practice. Columbia, CT: Learner's Dimension.

Canfield, A. A., \& Canfield, J. S. (1988). Canfield instructional styles inventory (ISI) manual. Los Angeles, CA: Western Psychological Services.

ChanLin, L. J. (2009). Use of learning strategies in web-based project tasks. Proceedings of the World Conference on Educational Multimedia, Hypermedia \& Telecommunications, ED-MEDIA 2009. London, 19-20 March 2009, 1677-1682.

Corbett, S. S., \& Smith, W. F. (1984). Identifying student learning styles: Proceed with caution! Modern Language Journal, 68, 212221.

Dale, E. (1969). Audio-visual methods in teaching (3rd ed.). New York: Holt, Rinehart and Winston.

Davidman, L. (1981). Learning style: The myth, the panacea, the wisdom. The Phi Delta Kappan, 62, 641-645.

Dede, C., Brown-L'Bahy, T., Ketelhut, D., \& Whitehouse, P. (2004). Distance learning (virtual learning). In Bidgoli, H. (Ed.), The internet encyclopedia (pp. 549-560). New York: Wiley. http://dx.doi.org/10.1002/047148296X.tie047

Diaz, D., \& Cartnal, R. (1999). Comparing student learning styles in an online distance learning class $\&$ an equivalent on-campus class. College Teaching, 47, 130-135.

http://home.earthlink.net/ davidpdiaz/LTS/html_docs/grslss.htm

Dunn, R. (1983). Can students identify their own learning style? Educational Leadership, 40, 60-62.

Ennis, R. H. (2000). Goals for a critical thinking curriculum \& its assessment. In A. L. Costa (Ed.), Developing minds: A resource book for teaching thinking (pp. 44-46). Alexandria, VA: ASCD.

Ehrman, M. (1996). Second language learning difficulties: Looking beneath the surface. Thousand Oaks, CA: Sage.

Felder, R., \& Brent, R. (2005). Understanding student differences. Journal of Engineering Education, 94, 57-72. http://dx.doi.org/10.1002/j.2168-9830.2005.tb00829.x

Felder, R., \& Silverman, L. (1988). Learning and teaching styles in engineering education. Engineering Education, 78, 674-681.

Fischer, B., \& Fischer, L. (1979). Styles in teaching \& learning. Educational Leadership, 36, 245-254.

Ford, N., \& Chen, S. (2000). Individual differences, hypermedia, navigation, and learning: An empirical study. Journal of Educational Multimedia and Hypermedia, 9, 281-311.
Friedman, P., \& Alley, R. (1984). Learning/teaching styles: Applying the principles. Theory Into Practice, 23, 77-81. http://dx.doi.org/10.1080/00405848409543093

Glaser, R. (1984). Education \& thinking: The role of knowledge. American Psychologist, 39, 93-104.

Graf, S., Lin, T., and Kinshuk (2008). The relationship between learning styles \& cognitive traits - Getting additional information for improving student modeling. Computers in Human Behavior, 24, 122137. http://dx.doi.org/10.1016/j.chb.2007.01.004

Gregorc, A.F. (1979a). Learning/teaching styles: Potent forces behind them. Educational Leadership, 5, 234-237.

Hornby, A. S. (2006). Oxford advanced learner's dictionary. New York: Oxford University Press.

Hsieh, S.-W., Jang, Y.-R., Hwang, G.-J., and Chen, N.-S. (2011). Effects of teaching \& learning styles on students' reflection levels for ubiquitous learning. Computers \& Education, 57, 1194-1201. http://dx.doi.org/10.1016/j.compedu.2011.01.004

James, W. B., \& Blank, W. E. (1993). Review \& critique of available learning-style instruments for adults. New Directions for Adult \& Continuing Education, 59, 47-57. http://dx.doi.org/10.1002/ace.36719935907

Jensen, E. (1998). Introduction to brain-compatible learning. San Diego, CA: The Brain Store, Inc.

Keefe, J. W. (1991). Learning style: Cognitive \& thinking skills. Reston, VA: National Association of Secondary School Principals.

Kolb, A. Y., \& Kolb, D. A. (2009). The learning way: Meta-cognitive aspects of experiential learning. Simulation \& Gaming, 40, 297-327. http://dx.doi.org/10.1177/1046878108325713

KoIb, D. A. (1984). Experiential learning: Experience as the source of learning and development. Englewood Cliffs, NJ: Prentice-Hall.

Kolb, D. A., Boyatzis, R., \& Mainemelis, C. (2001). Experiential learning theory: Previous research \& new directions. In R. Sternberg, \& L. Zhang (Eds.), Perspectives on cognitive learning \& thinking styles (pp. 228-247). Mahwah, NJ: Lawrence Erlbaum Associates.

Lawrence, G. (1982). People types and tiger stripes: A practical guide to learning styles (2nd ed.). Gainesville, FL: Center for Applications of Psychological Type.

Lawrence, G. 1993. People Types \& Tiger Stripes: A Practical Guide to Learning Styles, 3rd edition. Gainesville, FL: Center for Applications of Psychological Type.

McDermott, P. A., \& Beitman, B. S. (1984). Standardization of a scale for the study of children's learning styles: Structure, stability, and criterion validity. Psychology in the Schools, 21, 5-14. http://dx.doi.org/10.1002/1520-6807(198401)21:1<5::AID-PITS2310 210102>3.0.CO;2-B

McLaughlin, B. (1981). Theory \& research in second language learning: An emerging paradigm. Language Learning, 30, 331-350. http://dx.doi.org/10.1111/j.1467-1770.1980.tb00322.x

Miller, P. (2001). Learning styles: The multimedia of the mind. Programs ED 451340.

Myers, L. B., \& Myers, P. B. (1980). Gifts differing. Palo Alto, CA: Consulting Psychologists Press.

Paris, S. G., \& Winograd, P. (1990). Promoting metacognition \& motivationofex ceptional children. Remedial \& Special Education, 11, 7-15. http://dx.doi.org/10.1177/074193259001100604

Reid, J. M. (1995). Learning styles in the ESL/EFL classroom. Florence, KY: Heinle \& Heinle Publishers.

Reiff, J. C. (1992). Learning styles. What research says to the teacher, 7. Washington, DC: National Education Association.

Reinert, H. (1970). The Edmonds learning style identification exercise. Edmonds, WA: Edmonds School District.

Rose, C. (1998). Accelerated learning. New York: Bantam Dell Publishing Group.

Schmeck, R. R. (1988). Strategies \& styles of learning: An integration of varied perspectives. In R. R. Schmeck (Ed.), Learning strategies and learning styles. New York: Plenum Press. http://dx.doi.org/10.1007/978-1-4899-2118-5

Sewall, T. J. (1986). The measurement of learning style: A critique of four assessment tools. Madison, WI: Wisconsin University.

Shih, C., \& Gamon, J. (2002). Relationships among learning strategies, patterns, styles, \& achievement in web-based courses. Journal of Ag- 
ricultural Education, 43, 1-11.

http://pubs.aged.tamu.edu/jae/pdf/Vol43/43-04-01.pdf

Shuell, T. J. (1986). Cognitive conceptions of learning. Review of Educational Research, 56, 411-436.

http://dx.doi.org/10.3102/00346543056004411

Smith, L. H., \& J. S. Renzulli (1984). Learning style preferences: A practical approach for classroom teachers. Theory into Practice, 23, 44-50.

Syler, R., Cegielski, C., Oswald, S., \& Rainer, R. (2006). Examining drivers of course performance: An exploratory examination of an introductory CIS applications course. Decision Sciences Journal of Innovative Education, 4, 51-65.

http://dx.doi.org/10.1111/j.1540-4609.2006.00101.x

Thorton, B., Haskell, H., \& Libby, L. (2006). A comparison of learning styles between gifted and non-gifted high school students. Individual Differences Research, 4, 106-110.

Wadsworth, L. M., Husman, J., \& Duggan, M. A. (2007). Online mathematics achievement: Effects of learning strategies and self-ef- ficacy. Journal of Development Education, 30, 6-14.

Weinstein, C. E. (1996). Learning how to learn: An essential skill for the 21 st century. The Educational Record, 77, 49-52.

Werner, K. (2003). Learning style awareness and the appropriate prescription of study strategies to improve student understanding of work/study habits. Doctoral Dissertation, Anchorage, AK: University of Alaska Anchorage.

Whitman, N., \& Schwenk, T. L. (1984). Preceptors as teachers: A guide to clinical teaching. Salt Lake City, UT: University of Utah School of Medicine.

Zimmerman, B, J, \& Schunk, D. H. (2001). Self-regulated learning \& academic achievement: Theoretical perspectives ( $2 \mathrm{nd}$ ed.). Mahwah, NJ: Lawrence Erlbaum Associates.

Zualkernan, I., Allert, J., \& Qadah, G. (2006). Learning styles of computer programming students: A Middle Eastern \& American comparison. IEEE Transactions on Education, 49, 443-450.

http://dx.doi.org/10.1109/TE.2006.882366 